\title{
Manipulating Inoculum Densities of Verticillium dahliae and Pratylenchus penetrans with Green Manure Amendments and Solarization Influence Potato Yield
}

\author{
A. E. MacGuidwin, D. L. Knuteson, T. Connell, W. L. Bland, and K. D. Bartelt
}

First author: Department of Plant Pathology, University of Wisconsin, Madison 53706; second author: Department of Horticulture, University of Wisconsin, Madison 53706; third author: 1341 150th St., Cameron, IL 61423; and fourth and fifth authors: Soil Science Department, University of Wisconsin, Madison 53706.

Accepted for publication 4 January 2012.

\begin{abstract}
MacGuidwin, A. E., Knuteson, D. L., Connell, T., Bland, W. L., and Bartelt, K. D. 2012. Manipulating inoculum densities of Verticillium dahliae and Pratylenchus penetrans with green manure amendments and solarization influence potato yield. Phytopathology 102:519-527.

We used cover crops with demonstrated efficacy against Verticillium dahliae and Pratylenchus penetrans in combination with the biocidal practice of solarization to determine the importance of targeting both organisms for managing potato early dying, an issue relevant to the search for alternatives to soil fumigation. Two experiments were conducted in commercial fields using a split-plot design with cover crop treatments of rapeseed, marigold, forage pearl millet, sorghum-sudangrass, and corn as

were grown and solarization applied in year one, followed by potato in year two. The main effect of solarization was significant for reduced inoculum levels of both organisms in year two and increased tuber yields. The main effect of cover crop was also significant with lower population densities of $P$. penetrans following the marigold and millet treatments and of $V$. dahliae following rape and sorghum-sudangrass. The cover crop treatments influenced yield in only one of the experiments in the absence of solarization. The combinatorial effect of cover crops and solarization resulted in a wide range of pathogen population densities. Mean soil inoculum levels were negatively related to yield for $V$. dahliae in experiment 1 , and for $P$. penetrans and the $P$. penetrans $\times V$. dahliae interaction in both experiments.
\end{abstract} the main plot factor and solarization as the subplot factor. Cover crops
The root lesion nematode Pratylenchus penetrans and the wilt fungus Verticillium dahliae are important and common pathogens of potato causing decreased yield and tuber quality $(3,26)$. Plants with concomitant infection display leaf senescence at an accelerated rate $(31)$ and greater yield loss $(21,23)$ than caused by $V$. dahliae alone. The disease that results from both pathogens, with additional collaborators in some cases, is referred to as potato early dying (PED) and generally distinguished from Verticillium wilt, the disease caused by $V$. dahliae alone (30). Studies in Ohio showed yield loss of potato was correlated with population densities of pathogens early in the season $(10,39)$. The PED disease affects many potato varieties grown in a wide range of soil types across the Eastern and North Central United States and Eastern Canada (30). Soil fumigation with metam sodium is the most widely used practice to reduce initial population densities of PED pathogens and is indispensable in many potato production regions (30).

Alternatives to metam sodium for managing $V$. dahliae and $P$. penetrans are needed because of issues of cost, inconsistent performance due to biodegradation (38), and increased restrictions for fumigant application $(16,17,19)$. The market for organic potatoes is promising as the demand for organic produce increases (14), so alternatives to soil fumigation would be valuable. The fungus and nematode proliferate in different plant organs, have disparate life cycles, and vary in their host range, so biologically based practices tend to be pathogen specific compared with the

Corresponding author: A. E. MacGuidwin; E-mail address: aem@plantpath.wisc.edu

http://dx.doi.org/10.1094/PHYTO-07-11-0197

(c) 2012 The American Phytopathological Society biocidal soil fumigants. Research efforts for potato have been primarily focused on Verticillium wilt $(7,8,25,35,41)$ or $P$. penetrans $(1,3,4,15)$ as solitary pathogens.

Forage pearl millet, Pennesetum glaucum, and African marigold, Tagetes erecta, have demonstrated efficacy against $P$. penetrans. Canadian studies showed forage pearl millet to be economical and comparable to soil fumigation for reducing population densities of $P$. penetrans $(2,4,5,33)$. Marigold was also successful in reducing $P$. penetrans when planted as an early crop the same year as potato (1). Neither African marigold nor forage pearl millet is known to suppress $V$. dahliae and some isolates of the fungus were reported to colonize T. erecta (13).

Rapeseed, Brassica napus, and sudangrass, Sorghum sudenses, incorporated into soil as green manures were effective in reducing population densities of $V$. dahliae $(7,25,27)$, but not $P$. penetrans (16) in field studies. Disease symptoms of potato caused by Verticillium spp. were reduced and yields were enhanced, but there was not a consistent correspondence between population densities of $V$. dahliae, symptom severity, and potato yield $(7,25)$. Population densities of $P$. penetrans in the field were maintained on sudangrass $(16,20,27)$ and increased on rapeseed (16). Adding amendments of rapeseed seed meal suppressed $P$. penetrans (24), so the lack of efficacy for rapeseed plant amendments is probably due to the high level of nematode reproduction during the growth phase of the cover crop. Sudangrass is a poor host for P. penetrans when nematode densities are scaled to root weight $(5,36)$, but can support large populations in the field due to the immense root mass of the crop.

Manipulating the soil environment by heating soil through solarization or managing the decomposition of organic amendments is effective against many soil pathogens including $V$. dahliae and $P$. penetrans. Clear plastic films placed on bare soil reduced 
population densities of $V$. dahliae and $P$. penetrans $(19,28)$ and $V$. dahliae and Pratylenchus spp. (9) in field studies. Solarization following the incorporation of rape and sudangrass (27) or broccoli (34) cover crops as green manures reduced V. dahliae. A cut ryegrass crop that decomposed anaerobically under tarps designed to exclude oxygen rather to conduct solar heat reduced $V$. dahliae and $P$. fallax more than solarization or the cover crop alone (12).

Adoption of cultural practices to manage PED is constrained by the variable success in matching the current standard set by soil fumigation. Given the biocidal properties of fumigant pesticides, we hypothesized that reducing the mean initial inoculum of both $V$. dahliae and $P$. penetrans is critical for achieving yield in fields at risk for PED. We manipulated population densities of both pathogens using cultural practices with demonstrated efficacy against one or both pathogens. Specifically, we evaluated five cover crops incorporated as green amendments in combination with solarization for reducing densities of $V$. dahliae and $P$. penetrans and promoting yield in the potato crop that followed. Solarization is not a common practice in the North Central United States, so the efficacy of this practice for managing PED was of interest.

\section{MATERIALS AND METHODS}

Two field experiments were conducted in commercial fields in central Wisconsin with a history of PED and separated by about $16 \mathrm{~km}$. Both sites were a loamy sand soil (85\% sand, $6 \%$ silt, and $9 \%$ clay for experiment $1 ; 83 \%$ sand, $10 \%$ silt, and $7 \%$ clay for experiment 2) and farmed by the same enterprise using a 3-year rotation of corn, soybean, and potato. Irrigation and all field activities, except where stated, were performed by the farm enterprise following production practices common to the region. Experiment 2 began 1 year after experiment 1 . Each experiment occurred over 2 years (2004 to 2005 and 2005 to 2006) with treatments applied in year one when the field, except for the experiment, was planted with soybean and followed by potato in year two. The experimental design was a split plot with cover crop as the main plot factor and + or - solarization as the subplot factor. At the beginning of the study, eight sites were designated along the edge of the experiment, but under the cultivation regime of the entire field, as the "farm standard" for comparison purposes. Four of these sites were eventually fumigated in October of year one with metam sodium and four remained nonfumigated.

Year one-cover crops and solarization. The fields were planted with soybean in early May. On 20 May and 17 May for experiments 1 and 2, respectively, the soybeans on the site of the experiment were destroyed using tillage and five cover crops were planted in 20 main plots, each $18.29 \mathrm{~m}$ long (in the direction of the soybean rows) and $30.48 \mathrm{~m}$ wide. The main plots were in a contiguous linear configuration with no alleys. The entire experiment was $11,150 \mathrm{~m}^{2}$ in size.

The cover crops were field corn (Zea mays 105-day hybrid), sorghum-sudangrass (Sorghum bicolor $\times S$. Sudanese 'Honey Sweet'), rape (Brassica napus 'Dwarf Essex'), African marigold (Tagetes erecta 'Deep Orangeade'), and forage pearl millet (Pennesetum glaucum 'PP102M' for experiment 1 and 'Leafy Green' for experiment 2). Seed was spread broadcast on the soil surface and incorporated by raking at a seeding rate of $3.36,11.22$, and $28.02 \mathrm{~kg} \mathrm{ha}^{-1}$, respectively, for marigold, rape, and millet crops and $44.82 \mathrm{~kg} / \mathrm{ha}$ for corn and sorghum-sudangrass. Ammonium nitrate fertilizer was applied at a rate of $66 \mathrm{~kg} \mathrm{ha}^{-1}$, once in June and once in the first week in July. The experiment was irrigated on the same schedule as the soybean crop.

The solarization treatments were applied the last week in July and assigned randomly to the north or south side of each main plot. The day before incorporating the cover crops, the fields were irrigated and two $0.55-\mathrm{m}^{2}$ biomass samples were collected at randomly selected locations from each of the 40 subplots. On 20 July (experiment 1 ) and 19 July (experiment 2 ) the crops were disked twice to bury the vegetation and the solarization treatment was applied. The area to be solarized was delimited by digging trenches about $30 \mathrm{~cm}$ deep. Clear 4-mil polyethylene film tarps $(13.72 \mathrm{~m} \times 7.32 \mathrm{~m})$ were positioned by hand, pulled tight, and secured by burying the edges in the trenches. The solarized area within each plot was approximately $82 \mathrm{~m}^{2}$. The boundaries of the plots were georeferenced at submeter accuracy using a Trimble differential GPS backpack unit and a Trimble data logger (Trimble Navigation, Sunnyvale, CA). Data from a weather station located ca. $56 \mathrm{~km}$ south of the experiment showed that during the period of solarization air temperature ranged from 21.1 to $31.5^{\circ} \mathrm{C}$ (median $=28.2^{\circ} \mathrm{C}$ ) for experiment 1 and 14.3 to $32.7^{\circ} \mathrm{C}$ (median $=$ $26.1^{\circ} \mathrm{C}$ ) for experiment 2 . The percentage of the day that was clear of cloud cover ranged from 38.4 to $92 \%$ (median $=80.5 \%$ ) for experiment 1 and 11.8 to $92.6 \%$ (median $=75.5 \%$ ) for experiment 2.

Temperature probes (Hobo H8 Pro, Onset Computer Corp.) were positioned before the tarps were applied. In experiment 1 , soil temperature was recorded at a depth of $2 \mathrm{~cm}$ in one solarized plot for marigold, millet, rape, and sorghum-sudangrass. An additional solarized plot of rape, marigold, and millet was monitored at a depth of $20 \mathrm{~cm}$. Temperature data were also collected in one nonsolarized marigold plot at depths of 2, 20, and $100 \mathrm{~cm}$. In experiment 2 , temperature probes were place at depths of 1.5 and $15 \mathrm{~cm}$ in solarized and nonsolarized plots of marigold, millet, and sorghum-sudangrass. Soil temperature was recorded every $30 \mathrm{~min}$ in both experiments.

The tarps were removed on 5 August for experiment 1 and 30 September for experiment 2. Solarization was terminated after 16 days in the first experiment because the tarps ripped. Equipment used to maintain and harvest the soybean crop did not enter the experimental sites. The fields were fumigated with metam sodium in October at a rate of 39 liters/ha. The experiment and a $6-\mathrm{m}$ border of the surrounding land planted with soybean were not fumigated.

Year two-potato. The experiments were planted with potato the year following the cover crop and solarization treatments. Field preparation, planting, and crop maintenance were the same for the site of the experiment as for the rest of the field. The potato variety differed among experiments; 'Russet Burbank' for experiment 1 and 'Russet Norkotah' for experiment 2.

After vine desiccation but before the field was harvested, yield data were collected from the experiments by hand digging $3.05-\mathrm{m}$ sections from two rows in each of the 40 subplots. The potatoes were taken to a UW research facility for washing, weighing, and grading. Specific gravities and the incidence of internal defects were determined using a subsample of the tubers collected from each subplot.

Sampling and pathogen assays. Each subplot represented about $140 \mathrm{~m}^{2}$ of the cover crop treatment and about $90 \mathrm{~m}^{2}$ of the solarization treatment. Soil samples were collected from the area that corresponded to the solarization treatment on the days of planting the cover crops, applying the polyethylene tarps, after the first hard frost (8 October for experiment 1 and 31 September for experiment 2), in mid-April of the following year before spring tillage, and at potato harvest. Twelve cores of soil were collected to a depth of $15 \mathrm{~cm}$ using a 2.5-diameter sampling tube. It was not possible to include a fumigated check into the experiment due to the logistics of moving commercial fumigation equipment through the field, so eight locations on the perimeter of the experiment in the adjacent soybean crop were also sampled on all dates. Four of those locations were in an area not fumigated in October and four were in an area that was fumigated with 39 liter hal as was the rest of the field after soybean harvest. Soil samples were mixed well and subsampled for pathogen assays. 
Nematodes were recovered by passing a suspension of $100 \mathrm{~cm}^{3}$ of soil in water over 250 - and $38-\mu \mathrm{m}$ sieves nested together. Organic matter, including small root fragments, caught on the $38-\mu \mathrm{m}$ mesh sieve was incubated in Baermann Funnels for $48 \mathrm{~h}$. Material retained on the $250-\mu \mathrm{m}$ mesh sieve was suspended in sucrose and centrifuged to separate nematodes from the mineral fraction. Nematodes were observed using a stereomicroscope and the Pratylenchus spp. were counted. The data for the two assays were retained as separate counts for preliminary data analyses and combined for the final analysis. For this study, the metric of nematodes per $100 \mathrm{~cm}^{3}$ of soil represents nematodes recovered from bulk soil and those egressed from root fragments present within the soil. Species identification was based on the presence of males, number of lip annules, shape of the spermatheca, and other pertinent morphological characters.

The subsample assayed for $V$. dahliae was air-dried for 3 weeks before handling. Three $10-\mathrm{g}$ portions of soil were suspended in $100 \mathrm{ml}$ of water and stirred constantly as two 1-ml aliquots were removed. Each aliquot of the soil suspension was incubated on media semiselective for Verticillium (32), with a total of six petri dishes for each soil sample collected. Two weeks later, the surface of the agar was rinsed and colonies of $V$. dahliae were observed using a stereomicroscope and counted. The data were expressed as colony forming units (cfu) per gram of soil or per cubic centimeter of soil, using a value of $1.6 \mathrm{~g}$ per $\mathrm{cm}^{3}$ as the bulk density conversion factor. Potato stems were sampled to determine the incidence of $V$. dahliae when symptoms typical of PED first appeared in the potato crop. Stems were collected at 80 and 91 days after planting (DAP) for experiment 1 and at 52 and 66 DAP for experiment 2 from plants that were not used for yield. The stems were surface disinfested in a solution of $15 \%$ commercial bleach, rinsed in water, and then a cross section in the fourth internode from the first fully expanded leaf on the apical end was placed cut-side down on Sorenson's media (32) in a petri dish. Each stem section was scored for $V$. dahliae by counting the number of vascular bundles with microsclerotia growing into the agar after 3 weeks of growth. The data were collapsed into percent stems per plot positive or negative for $V$. dahliae for analysis.

Data analysis. Data were analyzed with Proc Mixed (SAS Institute, Cary, NC) using a one factor complete randomized block design for data sets collected before the solarization treatment was applied and a split-plot design with crop as the main factor and solarization as the subfactor after solarization occurred. Population densities of $P$. penetrans and $V$. dahliae were transformed using $\ln (x+1)$ to stabilize the variance. When appropriate, differences among the means for cover crop were tested using the CONTRAST statement, grouping "millet and marigold" versus "corn, sorghum sudangrass, and rape" for population densities of $P$. penetrans and $V$. dahliae based on a priori information on the host status of these crops for PED pathogens. Population densities of $P$. penetrans increased or were maintained in fields planted with corn, sorghum sudangrass, and rape $(1,2,4,5,33)$ and decreased in fields planted with marigold or forage pearl millet $(16,20,27)$. Population densities of $V$. dahliae decreased in fields planted with corn, sorghum sudangrass, and rape $(7,25,27)$, and the impact of marigold and forage pearl millet are not known. In cases where there was a significant cover crop-solarization interaction, the SLICE command was used to perform separate analyses. For measures relating to yield, differences among means were compared using least significant difference values modified with the Tukey adjustment. Significant main factor effects for yield were compared to the nonfumigated and fumigated reference data using Proc $t$ tests (SAS) and in the case where there was a significant crop-solarization interaction, the two crops with the lowest and highest nominal value were compared with the reference values. Regression analysis (Proc Reg) was used to examine the relationship of mean initial inoculum values for PED pathogen and total tuber yield, with the treatment structure of the experiment ignored. Regression equations were evaluated for significance of the overall $F$ statistic $(P \leq 0.05)$ and the estimated parameters for the variables on the basis of $t$ tests $(P \leq 0.05)$.

\section{RESULTS}

Soil samples collected prior to planting cover crops in year one of each experiment showed both sites to be infested with $P$. penetrans and $V$. dahliae at population densities representative of commercial fields in Wisconsin. There were no statistically significant differences among plots within an experiment for initial mean pathogen densities. The grand mean of $P$. penetrans was 40 and 72 per $100 \mathrm{~cm}^{3}$ of soil for experiments 1 and 2, respectively. The grand mean of $V$. dahliae was $3 \mathrm{cfu} \mathrm{g}^{-1}$ of soil in experiment 1 and $4 \mathrm{cfu} \mathrm{g}^{-1}$ of soil for experiment 2 .

Growth of the cover crops in year one. Establishment of the cover crops was hampered in experiment 1 due to rain and was good in experiment 2. In general, marigold and rape were less competitive with weeds than corn, millet, and sorghum-sudangrass. Estimates of dry matter accumulation after approximately 60 days of growth until incorporation was not different among the crops in experiment 1 (Table 1). For experiment 2, sorghumsudangrass produced about one and a half to three times more biomass than all but corn, and marigold produced the least. Even so, the mean biomass for marigold in experiment 2 was nearly double that of experiment 1 .

Solarization in year one. The solarization treatments were applied without incident, but the plastic film ripped in experiment 1 at 2 weeks after application so the covers were removed. There were only minor tears in the plastic film in experiment 2 and the covers were left in place until 20 September. There was some interference by animals with the covers, particularly birds and deer. The study sites were visited weekly and ripped plastic was repaired with duct tape. There was minimal growth of weeds under the covers and no regrowth of any cover crop. In nonsolarized plots, there was considerable regrowth of millet and sorghum-sudangrass, some regrowth of rape and marigold, and no regrowth of corn. Crop residues at the end of year one were left intact over the winter and incorporated in the spring before planting potato.

Soil temperature at a depth of 1.5 to $2 \mathrm{~cm}$ exceeded $45^{\circ} \mathrm{C}$ in solarized plots (Table 2). The maximum temperature in solarized marigold plots was elevated 11 to $12^{\circ} \mathrm{C}$ at the shallow depth by the soil covers. At greater depths, solarization increased soil temperature by about $7^{\circ} \mathrm{C}$ in experiment 1 . There was no increase detected for solarization at the $15-\mathrm{cm}$ depth in experiment 2 , but a comparison for the same cover crop with and without solarization was not possible because some of the plots had puddled water over the temperature probe, making the data unreliable. Data from experiment 1 were used to construct a model describing the relationship of soil depth and temperature. The model predicted

TABLE 1. Nematode densities and cover crop biomass at the time of incorporating African marigold, rapeseed, forage pearl millet, corn, or soghumsudangrass (SS) cover crops and applying solarization treatments ${ }^{\mathrm{y}}$

\begin{tabular}{lccccc}
\hline & \multicolumn{2}{l}{$\ln ($ nematodes +1$) 100 \mathrm{~cm}^{3}$} & & \multicolumn{2}{c}{ Biomass dry wt $\left(\mathrm{t} \mathrm{ha}^{-1}\right)^{\mathrm{z}}$} \\
\cline { 2 - 3 } \cline { 5 - 6 } Cover crop & Exp. one & Exp. two & & Exp. one & Exp. two \\
\hline Marigold & $2.4 \mathrm{a}$ & $3.9 \mathrm{a}$ & & $1.2 \mathrm{a}$ & $2.3 \mathrm{a}$ \\
Rape & $3.5 \mathrm{a}$ & $3.6 \mathrm{a}$ & & $1.1 \mathrm{a}$ & $3.7 \mathrm{ab}$ \\
Millet & $2.8 \mathrm{a}$ & $4.1 \mathrm{a}$ & & $0.6 \mathrm{a}$ & $4.5 \mathrm{abc}$ \\
Corn & $2.7 \mathrm{a}$ & $4.2 \mathrm{a}$ & & $1.1 \mathrm{a}$ & $6.1 \mathrm{bcd}$ \\
SS & $4.1 \mathrm{a}$ & $4.0 \mathrm{a}$ & & $1.3 \mathrm{a}$ & $7.3 \mathrm{~d}$ \\
\hline
\end{tabular}

y Nematodes were recovered from soil and the root fragments contained therein. Different letters denote statistical significance of $P<0.05$ using least square means adjusted by the Tukey-Kramer method.

z Samples include crop and weed biomass. 
soil temperature at $10 \mathrm{~cm}$ in excess of $40^{\circ} \mathrm{C}$ for 11 of the 14 days the polyethylene tarps were in place.

Effect of cover crops on PED pathogens. Cover crop main effects were significant for $P$. penetrans in both experiments (Fig. 1). At the time of incorporation 60 DAP, there were no statistically significant differences in nematode population densities among crops (Table 1). When the solarization covers were removed, the linear contrast of marigold and millet versus the other crops was statistically significant and continued into the potato year for experiment 2 (Fig. 1B). At the time potato was planted, mean initial inoculum densities of $P$. penetrans per $100 \mathrm{~cm}^{3}$ of soil by cover crop ranged from 18 to 82 for experiment 1 and 9 to 125 for experiment 2 . Nematode population densities rebounded on the potato crop, more so in experiment 1 than in experiment 2 . The mean population density of $P$. penetrans for the millet treatment at the conclusion of experiment 2 remained low relative to the other cover crop treatments, at 16 nematodes per $100 \mathrm{~cm}^{3}$ of soil.

Cover crop main effects were significant for $V$. dahliae, but the response varied depending on the life stage and habitat of the fungus. Verticillium in soil was only influenced by cover crop in experiment 1 (Fig. 2). Population densities of the fungus were lower in sorghum-sudangrass than in marigold plots after the plastic covers were removed. Mean soil inoculum density recovered in the spring of year two was lower in the former sorghumsudangrass and rape plots than corn and millet plots. The same trend was apparent in experiment 2 , but the differences were not statistically significant (data not shown). The lowest incidence of potato stem infection occurred in former millet plots, but the experiments differed as to when the effect was detected (Fig. 3). In experiment 1, millet was superior to the other cover crops on the second sampling date but not the first (data not shown). In experiment 2 , the effect was noted on only the first sampling date.

Effect of solarization on PED pathogens. Covering green crop residues with plastic film for solarization had a strong impact on population densities of both $V$. dahliae and $P$. penetrans with mean soil inoculum levels nominally lower in solarized subplots on all but one sampling date. The main effect of solarization was highly significant for nematodes at the time potatoes were planted and only marginally significant by the end of the potato season (Fig. 4). For Verticillium, the effect of solarization grew stronger with time, with the most significant benefit of solarization occurring at the end of the potato season (Fig. 5). There was a significant crop-solarization interaction for $V$. dahliae in experiment 2. Fewer $V$. dahliae were recovered from soil in solarized rape and millet plots $(P=0.01)$, but solarization did not affect $V$. dahliae for the other crops in that experiment.

Solarization main effects were weakly significant $(P=0.06)$ for the incidence of $V$. dahliae in potato stems for both experiments (data not shown). For experiment 1, more stems were positive for $V$. dahliae from solarized plots, with the effect strong in plots planted with corn (88\% versus $58 \%$ incidence) and rape $(75 \%$ versus $55 \%$ incidence), weak for sorghum-sudangrass ( $85 \%$ versus $80 \%)$, and absent for marigold (75\% versus $76 \%)$ and millet $(48 \%$ versus $48 \%$ ). For experiment 2 , solarized plots showed less stem infection and the magnitude of the difference ranged from $60 \%$ versus $95 \%$ for marigold to $20 \%$ versus $40 \%$ for millet. Symptoms of PED were severe in the nonfumigated reference area adjacent to the experiment during both years of the study, the progression of symptoms showing the same time course as in the experiment.

Yield and quality of the potato crop in year two. Solarizing cover crop residues increased potato yields for both experiments (Tables 3 and 4). Total yield and the yield of marketable tubers (US\#1) was increased $11 \%$ by solarization in experiment 1 . For experiment 2 , the effect of solarization varied by crop (cropsolarization interaction significant at $P=0.03$ ) and ranged from no difference for the marigold, millet, and sorghum-sudangrass treatments to a 39 and $27 \%$ increase in total yield for the corn and rape treatments, respectively. The main effect of cover crop treatment was not significant for experiment 1 , although the millet and marigold cover crop treatments were nominally greater for all yield parameters. For experiment 2, yields were similar among the cover crop treatments, ranging from 43.2 to $49.4 \mathrm{t} \mathrm{ha}^{-1}$ total yield for plots that were covered with plastic films. For plots not solarized, millet increased potato yield compared with corn and the contrast or "marigold and millet" versus "corn, sorghum-sudangrass, and corn" was significant $(P<0.05$, not shown in Table 4). Other measures of yield including the percentage of culls, and yield of tubers $>280 \mathrm{~g}$ (data not shown) had similar responses to the treatments as portrayed by yield of US\#1 sized potatoes and total yield.

There was notable disease in the nonfumigated reference plots, particularly in the second experiment when 'Russet Norkotah' was planted. For experiment 1, total potato yield and US\#1 yield in solarized plots was greater than the nonfumigated reference according to the $t$ test statistic $(P=0.01)$, and statistically com-

TABLE 2. Cumulative hours of exposure to elevated soil temperature and the maximum soil temperature achieved during the period of solarization (+ cover) for two field experiments

\begin{tabular}{|c|c|c|c|c|c|c|c|}
\hline \multirow[b]{2}{*}{ Experiment $^{\mathrm{w}}$} & \multirow[b]{2}{*}{ Depth $^{x}$} & \multirow[b]{2}{*}{ Treatment ${ }^{\mathrm{y}}$} & \multicolumn{5}{|c|}{ Cumulative hours of exposure } \\
\hline & & & $>30^{\circ} \mathrm{C}$ & $>35^{\circ} \mathrm{C}$ & $>40^{\circ} \mathrm{C}$ & $>45^{\circ} \mathrm{C}$ & $\operatorname{Max}^{\mathrm{z}}$ \\
\hline One & 2.0 & Marigold - cover & 65 & 4 & 0 & 0 & 35.8 \\
\hline One & 2.0 & Marigold + cover & 273 & 152 & 77 & 15 & 46.9 \\
\hline One & 2.0 & Millet + cover & 190 & 123 & 47 & 0 & 45.5 \\
\hline One & 2.0 & Rape + cover & 189 & 141 & 84 & 23 & 48.9 \\
\hline One & 2.0 & Sorghum sudangrass + cover & 195 & 142 & 91 & 29 & 49.1 \\
\hline One & 20.0 & Marigold - cover & 0 & 0 & 0 & 0 & 25.9 \\
\hline One & 20.0 & Marigold + cover & 79 & 0 & 0 & 0 & 32.8 \\
\hline One & 20.0 & Millet + cover & 119 & 0 & 0 & 0 & 32.7 \\
\hline One & 20.0 & Rape + cover & 42 & 0 & 0 & 0 & 32.2 \\
\hline Two & 1.5 & Mariglod - cover & 181 & 53 & 0 & 0 & 39.7 \\
\hline Two & 1.5 & Marigold + cover & 700 & 501 & 330 & 100 & 51.8 \\
\hline Two & 1.5 & Sorghum sudangrass + cover & 441 & 156 & 47 & 24 & 49.0 \\
\hline Two & 15.0 & Marigold + cover & 208 & 0 & 0 & 0 & 33.2 \\
\hline Two & 15.0 & Millet - cover & 110 & 0 & 0 & 0 & 32.3 \\
\hline Two & 15.0 & Sorghum sudangrass + cover & 44 & 0 & 0 & 0 & 31.5 \\
\hline
\end{tabular}

${ }^{w}$ Experiments one and two were conducted in different fields in different years.

${ }^{\mathrm{x}}$ Depth (centimeters) temperature probes were buried beneath the soil surface.

${ }^{y}$ Preceding cover crop with (+ cover) or without (- cover) solarization of amended crop residue. Data from six of the treatments are not presented because of bias caused by puddling of water on the tarp above the probe.

${ }^{\mathrm{z}}$ Maximum temperature recorded during the solarization period. 
parable to the fumigated reference. In experiment $2, t$ tests were used to compare the corn and millet treatments, with and without solarization to the reference plots. The millet treatment had yield greater than the nonfumigated reference $(P=0.01)$ and comparable to the fumigated reference regardless of solarization. The corn treatment without solarization had yield similar to the nonfumigated reference and less than $(P=0.01)$ the fumigated reference. Potato yield for the corn treatment with solarization was greater than the nonfumigated reference $(P=0.01)$.

Tuber specific gravity, a proxy measure for the dry matter fraction of tubers, was not influenced by solarization in either experiment, but was related to cover crop treatments in experiment 1 (Table 3). The millet treatment promoted tuber dry matter accumulation of 'Russet Burbank' compared with rape or sorghumsudangrass. Specific gravity values vary among potato cultivars, and the values for 'Russet Norkotah' in experiment 2 were lower and not affected by cover crop or solarization.
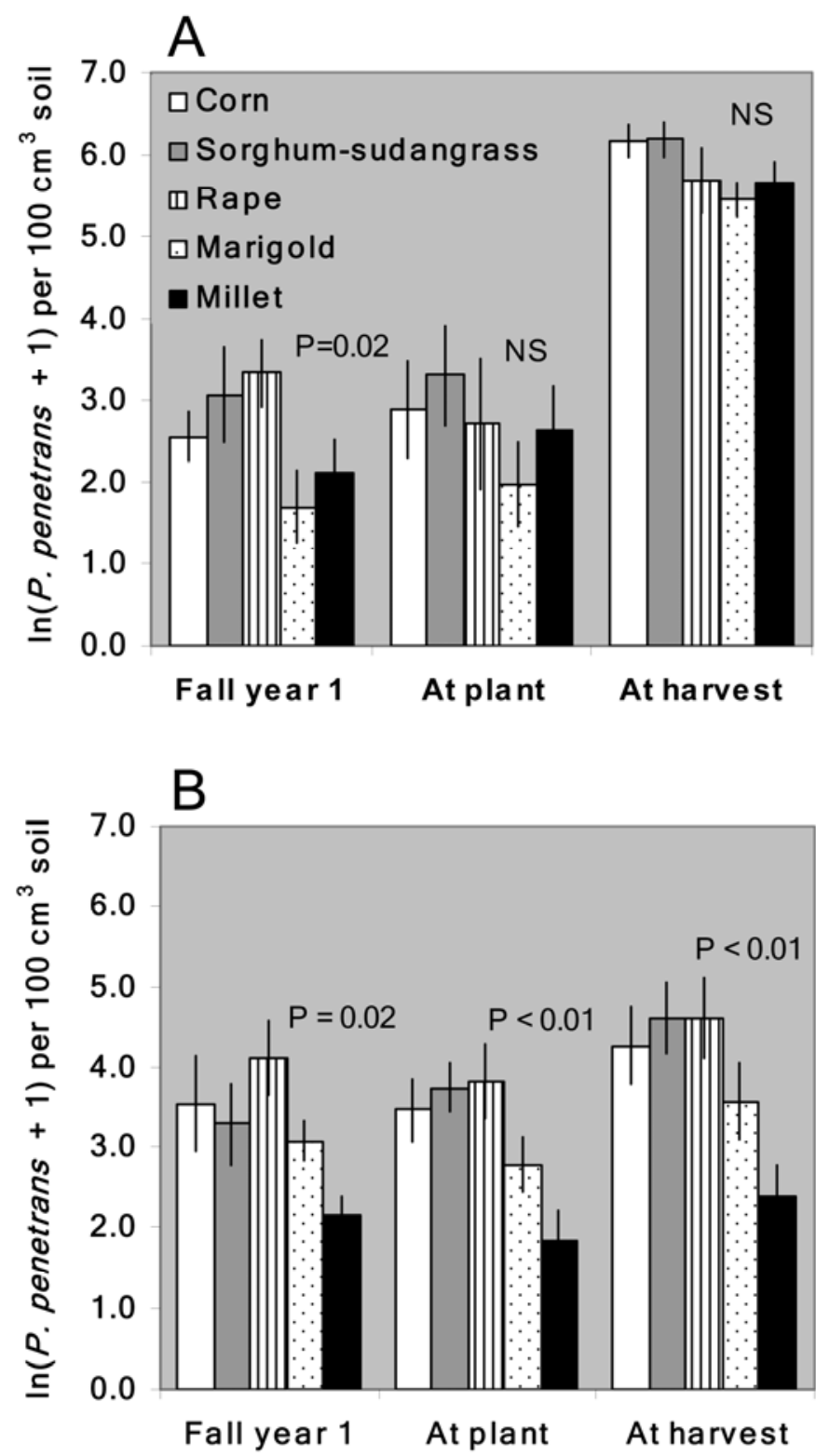

Fig. 1. Mean population densities ( \pm standard error) of Pratylenchus penetrans in $100 \mathrm{~cm}^{3}$ of soil the fall following corn, sorghum-sudangrass, rape, marigold, or forage pearl millet cover crops, the following spring when the potato crop was planted and in the fall when the potato crop was harvested in $\mathbf{A}$, experiments 1 and $\mathbf{B}$, experiment 2 . Significance of the linear contrast of marigold and forage pearl millet versus corn, sorghum-sudangrass, and rape is shown.
Another measure of potato quality is the percentage of internal tuber defects including hollow heart, internal brown spot, vascular browning, and stem end discoloration. The percentage of internal defects (data not shown) was significantly $(P=0.02)$ greater with solarization in experiment $1(22 \%$ versus $34 \%)$ and marginally significant $(P=0.06)$ in experiment $2(2 \%$ versus $4 \%)$. There were no significant crop effects on internal tuber defects. The overall rate of defects was greater in experiment 1 (grand mean $=28 \%$ ) than in experiment 2 (grand mean $=3 \%$ ) and exceeded that of the fumigated reference plot according to Student's $t$ tests $(P<0.05)$.

Relationship between pathogen inoculum densities and potato yield. The cover crop and solarization treatments resulted in a wide range of population densities for both $V$. dahliae and $P$. penetrans at the time potatoes were planted. For experiment 1, the mean initial inoculum ranged from 2 to $161 P$. penetrans per $100 \mathrm{~cm}^{3}$ of soil for the "marigold with solarization" and "rape without solarization" treatments, respectively, and 1 to $9 \mathrm{cfu}$ of $V$. dahliae $\mathrm{g}^{-1}$ of soil for the "rape with solarization" and "millet without solarization" treatments, respectively. For experiment 2, the mean initial inoculum ranged from 4 to $204 P$. penetrans per $100 \mathrm{~cm}^{3}$ of soil for the "millet with solarization" and "rape without solarization" treatments, respectively and 0 to $10 \mathrm{cfu}$ of $V$. dahliae $\mathrm{g}^{-1}$ of soil for the "rape with solarization" and "rape without solarization" treatments, respectively. Ignoring treatment, inoculum levels of PED pathogens at the time potatoes were planted was predictive of yield (Table 5). There was a significant negative linear relationship of total tuber yield to mean initial population densities of $P$. penetrans for both experiments and to $V$. dahliae for experiment 2. The models based on the interaction of both pathogens were also significant for both experiments.

\section{$\square$ Corn \\ $\square$ Marigold \\ Millet \\ m Rape}

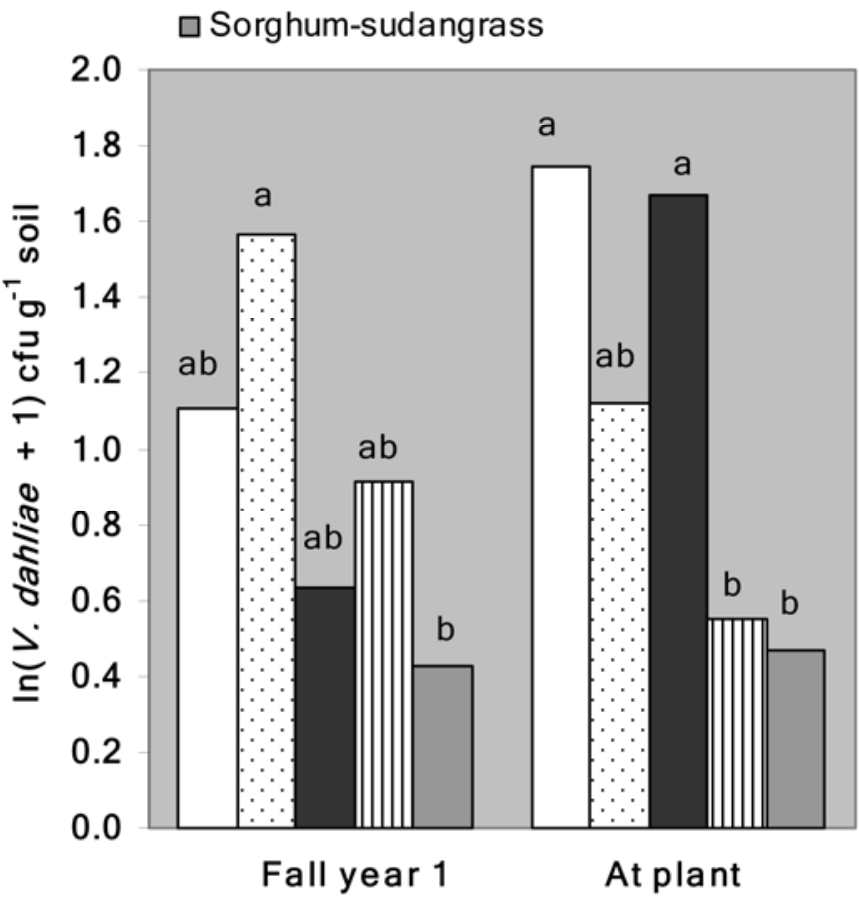

Fig. 2. Mean colony forming units of Verticillium dahliae recovered in $1 \mathrm{~g}$ of soil in the fall following corn, sorghum-sudangrass, rape, marigold, or forage pearl millet cover crops and in the following spring when the potato crop was planted in experiment 1 . 


\section{DISCUSSION}

Solarization of green cover crop amendments was more effective in reducing population densities of $V$. dahliae and $P$. penetrans than the amendments alone. The effect was apparent when

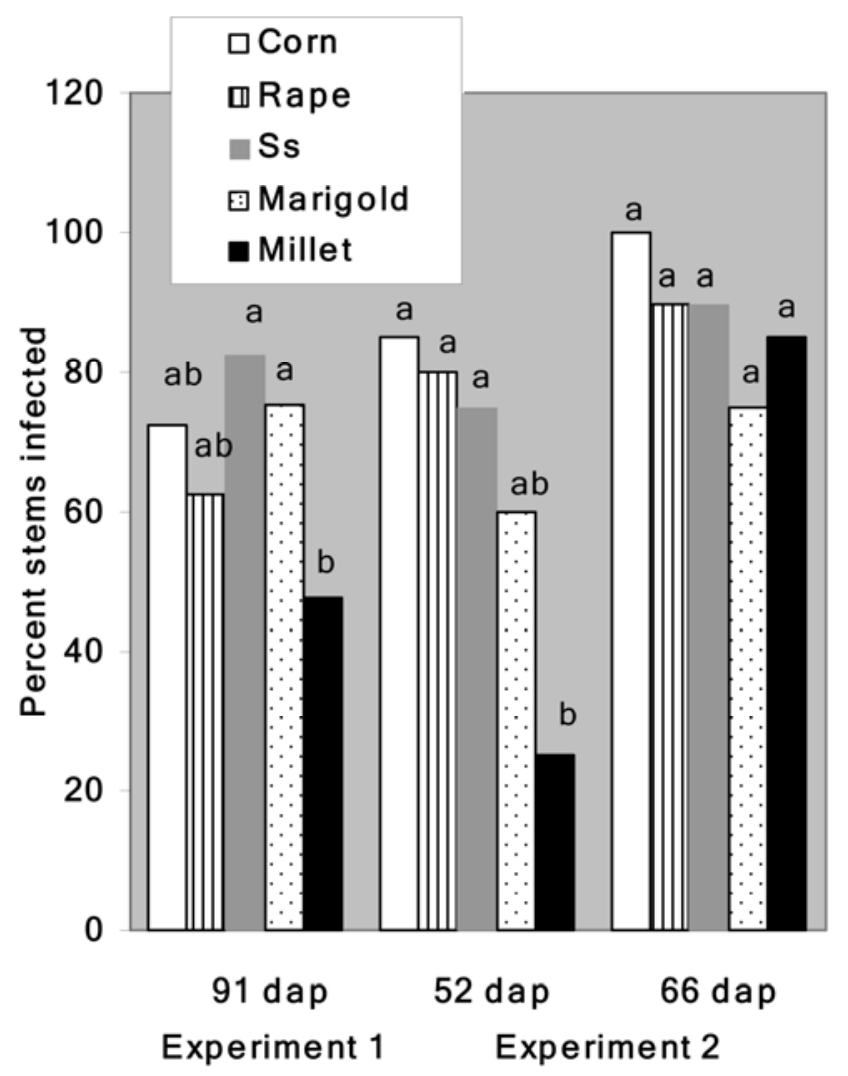

Fig. 3. Percentage of stems positive for Verticillium dahliae collected at 91 days after planting (dap) in experiment 1 and at 52 and 66 dap in experiment 2. the polyethylene film covers were removed and persisted for 9 and 12 months for nematodes and Verticillium spp., respectively. Our estimates of pathogen population densities were not biased by sampling date because every assay accounted for microsclerotia or nematodes free in the soil as well as those sheltered in roots, regardless of whether the roots were living or dead. For all but 1 of the 12 data sets of pathogen soil densities representing three dates and two experiments, the response to solarization was equivalent for the broad range of plant amendments suggesting that the mechanism of suppression was general or that multiple modes of action were responsible. We did not study the mechanism of pathogen reduction, but other studies have associated solarization with quantitative and qualitative changes in volatiles from decomposing plant tissues (11) or alterations in soil oxygen levels (6) in addition to soil heating.

Temperatures were high enough in the upper $20 \mathrm{~cm}$ of soil during solarization in our experiment to kill or inactivate some portion of the $V$. dahliae and $P$. penetrans populations. Previous studies determined under controlled conditions, LD90 values at $40^{\circ} \mathrm{C}$ to be 3 and $10 \mathrm{~h}$ for $V$. dahliae and $P$. penetrans, respectively (18). We exceeded these values at the shallow depths and achieved $30^{\circ} \mathrm{C}$ at the $15-\mathrm{cm}$ depth. Previous work showed $30^{\circ} \mathrm{C}$ sufficient to decrease the viability of microsclerotia over a 25-day period relative to 22 to $24^{\circ} \mathrm{C}(18)$ and to impede the life cycle of $P$. penetrans (22) or $V$. dahliae (37) compared with $25^{\circ} \mathrm{C}$. The elevated soil temperatures in our study may also have had indirect effects on PED pathogens as mediated through interactions with other organisms or changes in soil chemistry.

Population densities of $V$. dahliae and $P$. penetrans responded differently to the five cover crops used in this study, illustrating the challenge of managing PED using cropping practices. Marigold and forage pearl millet were poor hosts for P. penetrans, but maintained or increased levels of soil inoculum of $V$. dahliae compared with rapeseed or sorghum-sudangrass. The incidence of $V$. dahliae in potato shoots was lowest where forage pearl millet had been grown, at least for some portion of the growing season, and was not explained by mean inoculum densities of microsclerotia in soil. Under controlled conditions, coinfection of po-

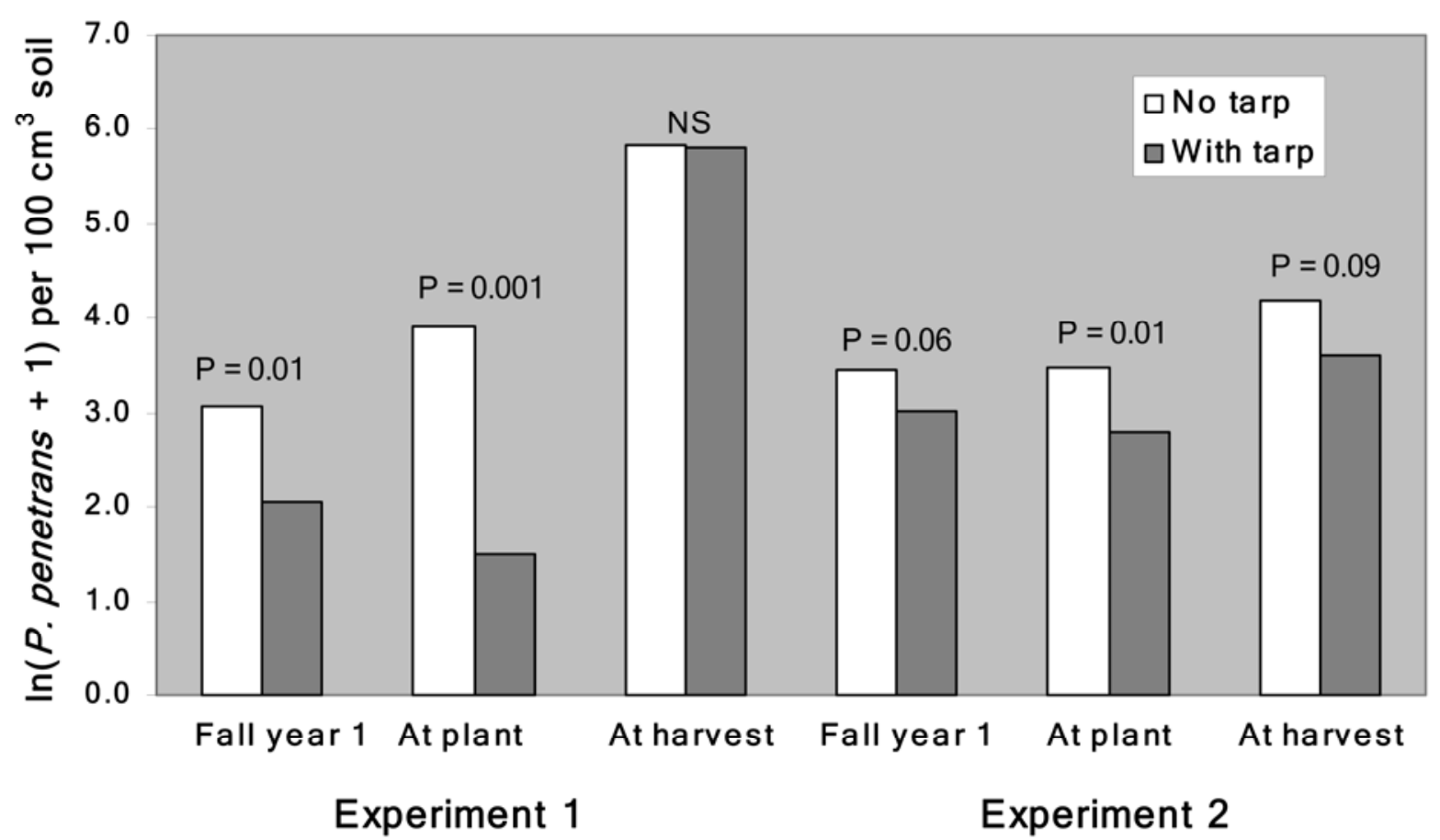

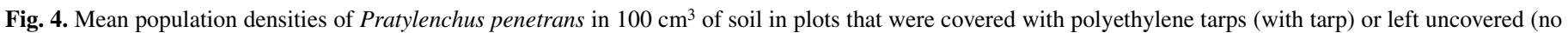

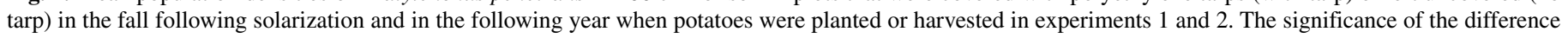
between the no-tarp and with-tarp treatments is shown. 
tato by $P$. penetrans was associated with elevated levels of colony forming units of $V$. dahliae in stems (29), so perhaps potato that followed forage pearl millet benefited because nematodes were suppressed.

There was a significant and substantial yield response of potato to the solarization treatments in both years of the study in two different fields $16 \mathrm{~km}$ apart. The greater difference between solarized and nonsolarized plots noted in experiment 2 was likely due to greater susceptibility of Russet Norkotah to PED compared with Russet Burbank. The effect of solarization on yield was greater than the influence of the cover crop planted preceding potato, but it is impossible to ascertain the interactive effects of the quality and quantity of crop residue and the conditions imposed by solarization on residue decomposition in this experiment. Incorporation of plant amendments can improve soil structure, influence soil water holding capacity, or alter the nutrient status of soils, which was presumed to be responsible for yield increase in the absence of PED pathogen suppression $(8,17)$. Regardless of additional ameliorative impacts of our treatments on the potato crop, our experiments showed a correspondence between the effects of treatments on PED pathogens and potato yield.

There was a quantitative relationship between potato yield and the initial inoculum densities of $P$. penetrans naturally occurring in two different potato fields, confirming the pathogenicity of this nematode for potato. One of seven commercial fields studied by Wheeler and Riedel (40) showed a negative liner relationship for preplant densities of $P$. penetrans and yield. Combining data from different microplot studies to create a range of inoculum densities ranging from 0 to 362 nematodes per $100 \mathrm{~cm}^{3}$ of soil, Francl et al. (10) explained yield loss of 'Superior' potato as a product of the initial inoculum of both $V$. dahliae and $P$. penetrans. A similar study by Wheeler et al. (39) developed a yield loss model for PED that assigned a qualitative $+/-$ role to $P$. penetrans. Our study supports the interactive model equating the importance of both $V$. dahliae and P. penetrans for the PED.

Our approach to manipulate population densities of natural infestations of $V$. dahliae and $P$. penetrans under commercial pro- duction conditions to study the relationship of mean inoculum levels and potato yield was unique. Yield loss for PED was modeled in previous studies using data from inoculated microplots $(10,39$, 40), and the natural variation in commercial fields (40). Reducing densities within subsets of an endemic population of pathogens is more realistic than field inoculations and provides more certainty in achieving desired combinatorial damage potentials than relying on the natural variation of pathogen densities in fields.

Solarization is not practiced for potato production in the North Central United States, but this study shows its potential for increasing tuber yield, with results comparable to soil fumigation

TABLE 3. Significant main effect means of cover crop and solarization treatments applied the year before growing potato on the yield and specific gravity of 'Russet Burbank' potato in experiment one

\begin{tabular}{llccc}
\hline & & \multicolumn{2}{c}{ Yield (t/ha) $^{\mathrm{z}}$} & \multirow{2}{*}{$\begin{array}{c}\text { Specific } \\
\text { Solarization }\end{array}$} \\
\cline { 3 - 4 } & Cover crop $^{\mathrm{x}}$ & Total & US \#1 & gravity \\
\hline Yes & & $50.2 \mathrm{a}$ & $47.2 \mathrm{a}$ & \\
No & & $44.9 \mathrm{~b}$ & $42.0 \mathrm{~b}$ & \\
Nonfumigated reference & & 42.4 & 39.5 & 1.0696 \\
Fumigated reference & & 51.1 & 48.1 & 1.0775 \\
& Rape & & & $1.0724 \mathrm{c}$ \\
& Sorghum-sudangrass & & & $1.0733 \mathrm{~cd}$ \\
& Corn & & & $1.0741 \mathrm{cde}$ \\
& Marigold & & & $1.0757 \mathrm{de}$ \\
& Forage pearl millet & & & $1.0768 \mathrm{e}$ \\
\hline
\end{tabular}

\footnotetext{
${ }^{\mathrm{x}}$ Polyethylene tarps were applied the year before planting potato after incorporating cover crops.

y Cover crops were grown the year before planting potato and incorporated as a green manure immediately before the solarization treatment.

${ }^{z}$ There was no significant interaction of solarization and cover crop effects. Means for solarization represent 20 plots. Means for cover crop represent eight plots. Means for the fumigated and nonfumigated reference represent four plots. Different letters within the comparisons for solarization main effect and cover crop main effect denote statistical significance of $P<0.05$ using least square means adjusted by the Tukey-Kramer method. Reference samples collected on the perimeter of the experiment were not included in the analysis.
}

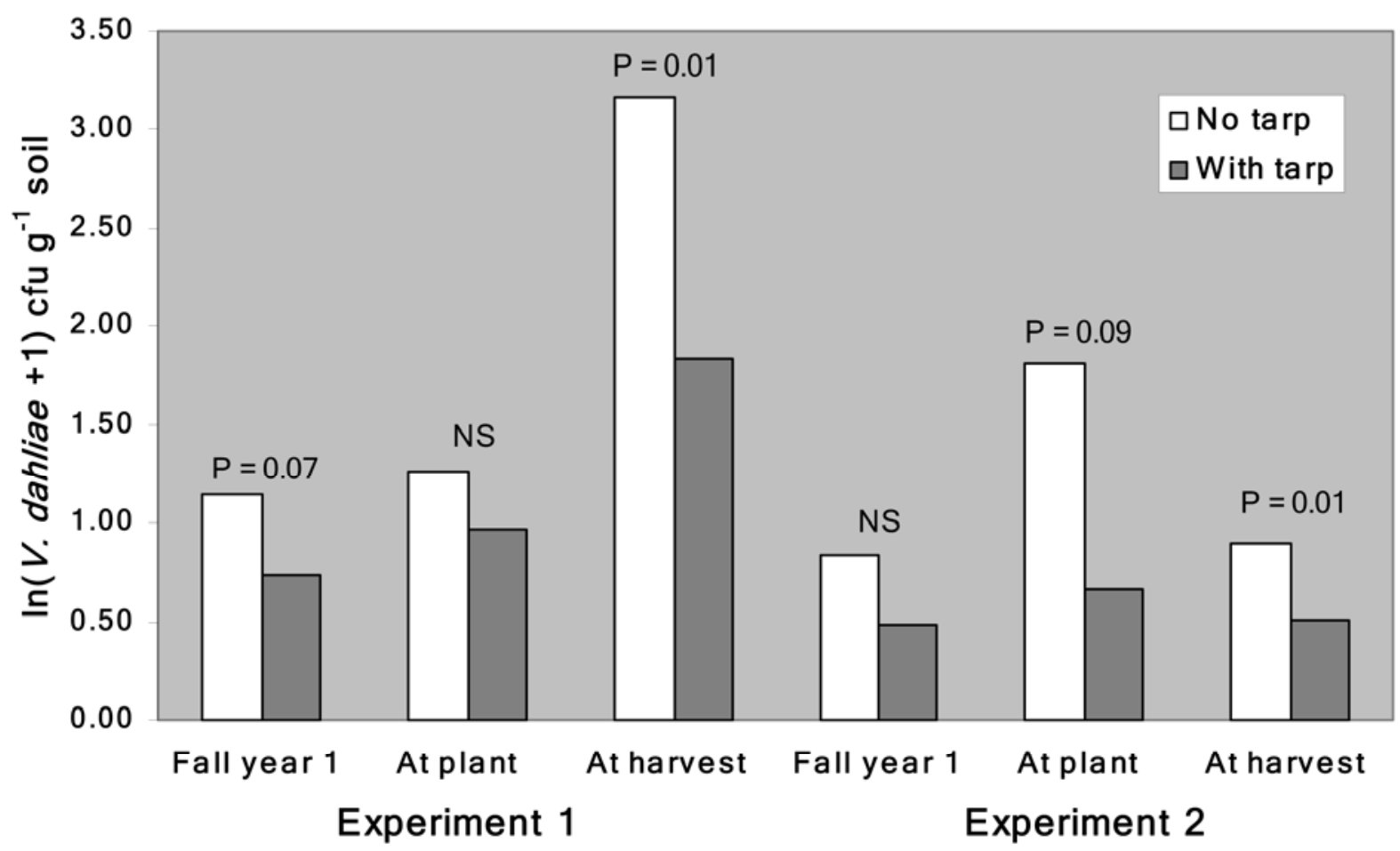

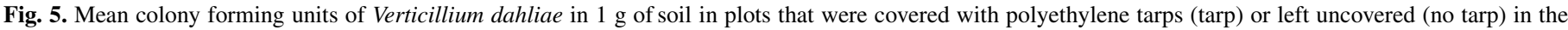

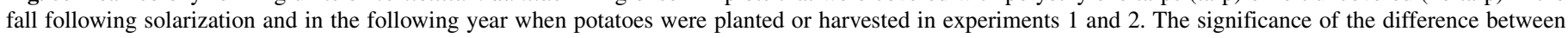
the no-tarp and with-tarp treatments is shown. 
TABLE 4. Significant effects of solarization treatments and the interaction of solarization and cover crops applied the year before growing potato on the yield of 'Russet Norkotah' potato in experiment two

\begin{tabular}{|c|c|c|c|}
\hline \multirow[b]{2}{*}{ Solarization $^{\mathrm{x}}$} & \multirow[b]{2}{*}{ Cover crop ${ }^{y}$} & \multicolumn{2}{|c|}{ Yield $(\mathrm{t} / \mathrm{ha})^{\mathrm{z}}$} \\
\hline & & Total & US \#1 \\
\hline Yes & & $46.7 \mathrm{a}$ & $42.9 \mathrm{a}$ \\
\hline No & & $38.8 \mathrm{~b}$ & $35.4 \mathrm{~b}$ \\
\hline Nonfumigated reference & & 23.7 & 20.7 \\
\hline Fumigated reference & & 49.6 & 45.1 \\
\hline \multirow[t]{5}{*}{ With solarization } & Corn & $48.2 \mathrm{c}$ & $44.5 \mathrm{c}$ \\
\hline & Rape & $49.4 \mathrm{c}$ & $46.5 \mathrm{c}$ \\
\hline & Sorghum sudangrass & $43.2 \mathrm{c}$ & $39.0 \mathrm{c}$ \\
\hline & Marigold & $45.9 \mathrm{c}$ & $42.6 \mathrm{c}$ \\
\hline & Forage pearl millet & $46.5 \mathrm{c}$ & $41.6 \mathrm{c}$ \\
\hline \multirow[t]{5}{*}{ Without solarization } & Corn & $29.4 \mathrm{c}$ & $26.9 \mathrm{c}$ \\
\hline & Rape & $35.9 \mathrm{~cd}$ & $32.1 \mathrm{~cd}$ \\
\hline & Sorghum sudangrass & $41.9 \mathrm{~cd}$ & $37.7 \mathrm{~cd}$ \\
\hline & Marigold & $41.5 \mathrm{~cd}$ & $38.3 \mathrm{~cd}$ \\
\hline & Forage pearl millet & $45.3 \mathrm{~d}$ & $41.9 \mathrm{~d}$ \\
\hline
\end{tabular}

x Polyethylene tarps were applied the year before planting potato after incorporating cover crops.

y Cover crops were grown the year before planting potato and incorporated as a green manure immediately before the solarization treatment.

$\mathrm{z}$ There was a significant interaction of solarization and cover crop effects. Means for solarization represent 20 plots. Means for solarization-cover crop represent four plots. Means for the fumigated and nonfumigated reference represent four plots. Different letters within the comparisons for solarization main effect or solarization-cover crop interaction denote statistical significance of $P<0.05$ using least square means adjusted by the Tukey-Kramer method. Reference samples collected on the perimeter of the experiment were not included in the analysis.

using metam sodium. Other solarization studies in temperate regions report successful outcomes for PED pathogens $(9,19,27)$ and potato yield (9), using solarization periods from 6 to 8 weeks or biological soil disinfestation (covering mulches with airtight plastic) for 10 to 13 weeks (12). Our intention was to leave soil covers in place for 8 weeks, and our serendipitous finding in experiment 1 that 2 weeks was sufficient to obtain statistically significant and economically relevant results supports the promise of this technology for PED management.

Organic amendments and residue management are used by growers and this study provides further evidence that forage pearl millet, African marigold, and sorghum-sudangrass are beneficial in potato rotations, collaborating previous studies $(4,8,33)$. Studies showing their efficacy in fields at risk for PED have used growth periods ranging from one to two full growing seasons. The possibilities of double-cropping these crops with a short season vegetable or harvesting them as a cash crop without loss of pathogen suppression need to be determined Many questions remain about the long-term utility of these crops as replacements for soil fumigation, but they offer an immediate addition to the arsenal of integrated pest management tactics for disease management.

Our study shows the important role that $P$. penetrans, as well as $V$. dahliae, plays in the PED disease. To maintain acceptable potato yield, alternative practices to soil fumigation should be effective against both pathogens, particularly in regards to reducing soil inoculum levels at the time potato is planted. Soil fumigation is an established and accepted practice to reduce PED pathogens, but this study demonstrates the potential for cultural practices to match that industry standard.

\section{ACKNOWLEDGMENTS}

This work was supported by grants from the Wisconsin Potato and Vegetable Growers Association, the "Wisconsin Healthy Grown" potato project, and USDA/CSREES-Methyl Bromide Alternatives Research Initiative Award Number 2003-51102-02043. We thank Plover River Farms, Inc., for their collaboration in this research, D. Rouse and A. Gevens for their helpful review of this manuscript, and to the many student workers who assisted with the project.
TABLE 5. Relationship of inoculum density of Pratylenchus penetrans, Verticillium dahliae, or both pathogens at the time potatoes were planted and total tuber yield

\begin{tabular}{llcccc}
\hline \multirow{2}{*}{ Experiment } & $\begin{array}{c}\text { Parameter } \\
\text { or response } \\
\text { variable }\end{array}$ & Estimate $\pm \mathrm{SE}$ & $t$ value & $P$ value & Adj. $R^{2}$ \\
\hline One & Intercept & $50.87 \pm 0.94$ & 53.92 & 0.01 & 0.69 \\
& $P$. penetrans & $-10.35 \pm 2.26$ & -4.59 & 0.01 & \\
One & Intercept & $47.79 \pm 2.68$ & 17.80 & 0.01 & 0.00 \\
& V. dahliae & $-0.06 \pm 1.74$ & -0.03 & 0.98 & \\
One & Intercept & $49.41 \pm 2.14$ & 23.11 & 0.01 & 0.00 \\
& Vd $\times$ Pp & $-0.18 \pm 0.19$ & -0.95 & 0.37 & \\
Two & Intercept & $48.87 \pm 2.84$ & 17.21 & 0.01 & 0.38 \\
& P. penetrans & $-19.56 \pm 7.62$ & -2.56 & 0.03 & \\
Two & Intercept & $50.10 \pm 3.05$ & 16.43 & 0.01 & 0.42 \\
& V. dahliae & $-4.84 \pm 1.76$ & -2.75 & 0.02 & \\
Two & Intercept & $51.15 \pm 2.93$ & 17.44 & 0.01 & 0.51 \\
& Vd $\times$ Pp & $-4.58 \pm 1.42$ & -3.23 & 0.01 & \\
Combined & Intercept & $0.98 \pm 0.03$ & 33.23 & 0.01 & 0.38 \\
& P. penetrans & $-0.27 \pm 0.07$ & -3.59 & 0.01 & \\
Combined & Intercept & $0.99 \pm 0.05$ & 21.91 & 0.01 & 0.17 \\
& V. dahliae & $-0.0 .06 \pm 0.03$ & -2.23 & 0.04 & \\
Combined & Intercept & $1.02 \pm 0.04$ & 23.52 & 0.01 & 0.33 \\
& Vd $\times$ Pp & $-0.07 \pm 0.02$ & -3.23 & 0.01 & \\
\hline
\end{tabular}

${ }^{y}$ Experiments one and two were conducted in different fields in different years.

${ }^{z}$ Population densitites of $P$. penetrans and $V$. dahliae per cubic centimeter of soil.

\section{LITERATURE CITED}

1. Alexander, S. A., and Waldenmaier, C. M. 2002. Suppression of Pratylenchus penetrans populations in potato and tomato using African marigolds. J. Nematol. 34:130-134.

2. Amankwa, G. A., White, A. D., McDowell, T. W., and Van Hooren, D. L. 2006. Pearl millet as a rotation crop with flue-cured tobacco for control of root-lesion nematodes in Ontario. Can. J. Plant Sci. 86:1265-1271.

3. Ball-Coelho, B., Bruin, A. J., Roy, R. C., and Riga, E. 2003. Forage pearl millet and marigold as rotation crops for biological control of root-lesion nematodes in potato. Agron. J. 95:282-292.

4. Belair, G., Dauphinais, N., Fournier, Y., Dangi, O. P., and Clement, M. F. 2005. Effect of forage and grain pearl millet on Pratylenchus penetrans and potato yields in Quebec. J. Nematol. 37:78-82.

5. Belair, G., Fournier, Y., Dauphinais, N., and Dangi, O. P. 2002. Reproduction of Pratylenchus penetrans on various rotation crops in Quebec. Phytoprotection 83:111-114.

6. Blok, W. J., Lamers, J. G., Termorshuizen, A. J., and Bollen, G. J. 2000. Control of soilborne plant pathogens by incorporating fresh organic amendments followed by tarping. Phytopathology 90:253-259.

7. Davis, J. R., Huisman, O. C., Westermann, D. T., Hafez, S. L., Everson, D. O., Sorensen, L. H., and Schneider, A. T. 1996. Effects of green manures on Verticillium wilt of potato. Phytopathology 86:444-453.

8. Davis, J. R., Huisman, O. C., Westermann, D. T., Everson, D. O., Schneider, A., and Sorensen, L. H. 2004. Some unique benefits with sudangrass for improved U.S. \#1 yields and size of Russet Burbank potato. Am. J. Potato Res. 81:403-413.

9. Davis, J. R., and Sorensen, L. H. 1986. Influence of soil solarization at moderate temperatures on potato genotypes with differing resistance to Verticillium dahliae. Phytopathology 76:1021-1026.

10. Francl, L. J., Madden, L. V., Rowe, R. C., and Riedel, R. M. 1987. Potato yield loss prediction and discrimination using preplant population densities of Verticillium dahliae and Pratylenchus penetrans. Phytopathology 77:379-584.

11. Gamliel, A., and Stapleton, J. J. 1993. Characterization of antifungal volatile compounds evolved from solarized soil amended with cabbage residues. Phytopathology 83:899-905.

12. Goud, J.-K. C., Termorshuizen, A. J., Blok, W. J., and van Bruggen, H. C. 2004. Long-term effect of cytological soil disinfestations on Verticillium wilt. Plant Dis. 88:688-694.

13. Hine, R. B., and McCain, A. H. 1984. Verticillium wilt of Tagetes spp. Plant Dis. 68:1098.

14. Hsieh, M.-F., Mitchell, P. D., and Stieger, K. W. 2009. Potato demand in an increasingly organic marketplace. Agribusiness 25:369-394. 
15. Kimpinski, J., Arsenault, W. J., Gallant, C. E., and Sanderson, J. B. 2000. The effect of marigolds (Tagetes spp.) and other cover crops on Pratylenchus penetrans and on following potato crops. Suppl. J. Nematol. 32(4s):531-536.

16. LaMondia, J. A. 2006. Management of lesion nematodes and potato early dying with rotation crops. J. Nematol. 38:442-448.

17. LaMondia, J. A., Gent, M. P. N., Ferrandino, F. J., and Elmer, W. H. 1999. Effect of compost amendment or straw mulch on potato early dying disease. Plant Dis. 83:361-366.

18. Lazarovits, G., Hawke, M. A., Olthof, Th. H. A., and Coutu-Sundy, J. 1991. Influence of temperature on survival of Pratylenchus penetrans and of microsclerotia of Verticillium in soil. Can. J. Plant Pathol. 13:106-111.

19. Lazarovits, G., Hawke, M. A., Tomlin, A. D., Olthof, Th. H. A., and Squire, S. 1991. Soil solarization to control Verticillium dahliae and Pratylenchus penetrans on potatoes in central Ontario. Can. J. Plant Pathol. 13:116-123.

20. MacGuidwin, A. E., and Layne, T. L. 1995. Response of nematode communities to sudangrass and sorghum-sudangrass hybrids grown as green manure crops. J. Nematol. 27:609-616.

21. MacGuidwin, A. E., and Rouse, D. I. 1990. Role of Pratylenchus penetrans in the potato early dying disease of Russet Burbank potato. Phytopathology 80:1077-1082.

22. Mamiya, Y. 1971. Effect of temperature on the life cycle of Pratylenchus penetrans on Cryptomeria seedlings and observations on its reproduction. Nematologica 17:82-92.

23. Martin, M. J., Riedel, R. M., and Rowe, R. C. 1982. Verticillium dahliae and Pratylenchus penetrans: Interactions in the early dying complex of potato in Ohio. Phytopathology 72:640-644.

24. Mazzola, M., Granatstein, D. M., Elfving, D. C., and Millinix, K. 2001. Suppression of specific apple root pathogens by Brassica napus seed meal amendment regardless of glucosinolate content. Phytopathology 91:673679.

25. Ochiai, N., Powelson, M. L., Dick, R. P., and Crowe, F. J. 2007. Effects of green manure type and amendment rate on Verticillium wilt severity and yield of Russet Burbank potato. Plant Dis. 91:400-406.

26. Olthof, Th. H. A. 1987. Effects of fumigants and systemic pesticides on Pratylenchus penetrans and potato yield. J. Nematol.19:424-430.

27. Pinkerton, J. N., Ivors, K. L., Miller, M. L., and Moore, L. W. 2000. Effect of soil solarization and cover crops on populations of selected soilborne plant pathogens in western Oregon. Plant Dis. 84:952-960.

28. Porter, I. J., and Merriman, P. R. 1983. Effects of solarization of soil on nematode and fungal pathogens at two sites in Victoria. Soil Biol.
Biochem. 15:39-44.

29. Rotenberg, D., MacGuidwin, A. E., Saeed, I. A. M., and Rouse, D. I. 2004. Interaction of spatially separated Pratylenchus penetrans and Verticillium dahliae on potato measured by impaired photosynthesis. Plant Pathol. 53:294-302.

30. Rowe, R. C., and Powelson, M. L. 2002. Potato early dying: Management challenges in a changing production environment. Plant Dis. 86:1184-1193.

31. Saeed, I. A. M., MacGuidwin, A. E., and Rouse, D. I. 1997. Disease progress based on effects of Verticillium dahliae and Pratylenchus penetrans on gas exchange in Russet Burbank potato. Phytopathology 87:440-445.

32. Sorensen, L. H., Scheider, A. T., and Davis, J. R. 1991. Influence of sodium polygalacturonate sources and improved recovery of Verticillium spp. from soil. Phytopathology 81:1347.

33. Sritharan, R., Potter, J. W., Anand Kumar, K., and Dangi, O. P. 2006. Crop rotation with forage peal millet for control of root-lesion nematodes in on-farm trials with potato. J. New Seeds 8:51-61.

34. Subbarao, K. V., Hubbard, J. C., and Koike, S. T. 1999. Evaluation of broccoli residue incorporation into field soil for Verticillium Wilt control in cauliflower. Plant Dis. 83:124-129.

35. Tenuta, M., Conn, K. L., and Lazarovitz, G. 2002. Volatile fatty acids in liquid swine manure can kill microsclerotia of Verticillium dahliae. Phytopathology 95:548-552.

36. Thies, J. A., Petersen, A. D., and Barnes, D. K. 1995. Host suitability of forage grasses and legumes for root-lesion nematode Pratylenchus penetrans. Crop Sci. 35:1647-1651.

37. Tjamos, E. C., and Fravel, D. R. 1995. Detrimental effects of sublethal heating and Talaromyces flavus on microsclerotia of Verticillium dahliae. Phytopathology 85:388-392.

38. Triky-Dotan, S., Austerweil, M., Steiner, B., Peretz-Alon, Y., Katan, J., and Gamliel, A. 2009. Accelerated degradation of metam-sodium in soil and consequences for root-disease management. Phytopathology 99:362368.

39. Wheeler, T. A., Madden, L. V., Rowe, R. C., and Riedel, R. M. 1992 Modeling of yield loss in potato early dying caused by Pratylenchus penetrans and Verticillium dahliae. J. Nematol. 24:99-102.

40. Wheeler, T. A., and Riedel, R. M. 1994. Interactions among Pratylenchus penetrans, $P$. scribneri, and Verticillium dahliae in the potato early dying disease complex. J. Nematol. 26:228-234.

41. Wiggins, B. E., and Kinkel, L. L. 2005. Green manures and crop sequences influence potato diseases and pathogen inhibitory activity of indigenous Streptomycetes. Phytopathology 95:178-185. 